\title{
FOLLOW THE ACTORS: \\ ETHNOGRAPHIC KEYS FOR UNDERSTANDING LEGAL ACTIVISM FOR CRIMINAL JUSTICE REFORM IN ARGENTINA
}

\begin{abstract}
JULIETA MIRA ${ }^{1}$
Abstract: This article presents the research backroom about the legal activism in the criminal justice system reform following the ethnographic strategy. In particular, it addresses the "struggle" for "accusatory" criminal procedural reform at the federal level in Argentina since the end of the last dictatorship (1976-1983). Specifically it is about: a) participation in public events as an entrée to the field; b) native etnographer; c) native categories and theoretical concepts; d) the cause-based "partisanism" (militancia) and legal activism; and e) reform flags as cosmologies of social order. Finally, the article offers an analysis of the benefits of ethnographic research with legal activists in the field of human rights.
\end{abstract}

Key words: Etnography, etnographer, criminal procedural reform, fieldwork, lawyers, human rights.

Summary: I.INTRODUCTION: THE RESEARCH OF THE LEGAL WORLD FROM INSIDE; II.THE BACKROOM OF RESEARCHING LEGAL ACTIVISM FOR THE REFORM OF THE FEDERAL CRIMINAL PROCEDURAL CODE IN ARGENTINA; II.1.Participation in public events: an entrée to the field; II.2.Native etnographer: The journey to the social world of lawyers; III.PRODUCING A COMPREHENSIVE PERSPECTIVE CONCERNING LAW FROM THE SOCIAL SCIENCES: NATIVE CATEGORIES AND THEORETICAL CONCEPTS; III.1.Cause-based "partisanism" (militancia) and legal activism; III.2.Reform flags as cosmologies of social order; IV.CONCLUSIONS: THE RESEARCH INTO THE LEGAL WORLD AS A JOURNEY

\section{INTRODUCTION: THE RESEARCH OF THE LEGAL WORLD FROM INSIDE}

This article presents the research backroom about lawyers and the criminal justice system reform following the ethnographic strategy typical of the anthropology. In particular, it addresses the "struggle" for "accusatory" criminal procedural reform at the federal level in Argentina, which might be regarded as having a strong impact on the Latinamerican region. Specifically, it is about the long socio-technical dispute for the reform of the Federal Criminal Procedural Code (Código Procesal Penal de la Nación). This statute is highly significant for human rights considering that it applies to the rules of criminal prosecution regarding federal offences, such as crimes against humanity, counterfeiting of money, human trafficking, drug dealing, terrorism, and corruption.

In the course of fieldwork, there was an opportunity to observe the reforming practices aimed at establishing an "accusatorial system" at the federal criminal procedure, which gained great force in Argentina since the end of the last dictatorship (1976-1983) and in successive democratic governments. To sum up, the research was able to detect the legal activism of a group of lawyers who positioned themselves as moral entrepreneurs in the dispute for the Criminal Justice reform, established networks of activism beyond Argentina, and dedicated their lives and careers to the cause of law.

\footnotetext{
${ }^{1}$ Universidad Nacional de San Martín (UNSAM), Argentina (julieta_mira@yahoo.com.ar).
} 
Moreover, this article presents both the main methodological results of my fieldwork ${ }^{2}$ and an analysis of my own research practice in the world of criminal law and human rights, as a path generated in the search for understanding the object of my research: the reform of the Federal Criminal Procedural Code. This reform aimed at establishing the so-called "accusatorial" system in Argentina comprising the following features: orality, publicity, prosecutor protagonism and constitutional guarantees during the proceedings. It is worthy to note that the reform attained great strength since the end of the last military dictatorship in 1983.

The effort of this analysis tries to deconstruct my own experience conducting the fieldwork. Moreover, it allows us to understand the progressive impact of ethnography both on the form of my research and my subjectivity as a researcher, since this methodological position puts into play the reflexivity, the implication and the alienation effect of who is doing research. The purpose of this objectification of my research work is to contribute to the visibility of the potential of ethnography applied to socio-legal research. This methodology of research makes it possible to understand concretely what the law is like rather than how it should be, because it does not seek a truth but tries instead to know the existing social practices in the legal field in general.

This shift is possible by transcending the focus on normativity, which opens the opportunity to discover the construction of the venue for relations and power around the law. The change returns the voice to the agents and helps visualize the causes $^{4}$ for which they fight. Furthermore, this perspective appreciates the "reformers" resources and

\footnotetext{
2 This work is part of my doctoral research, started in 2009 and ended in 2014, and carried out within the framework of the PhD Program of Social Sciences at the Faculty of Social Sciences of the University of Buenos Aires (Argentina). PhD thesis entitled: Una promesa de democratización. Activismo, política y expertise jurídica en el proceso de reforma de la justicia penal en la Argentina (A promise of democratization. Activism, politics and legal expertise in the process of criminal justice reform in Argentina), supervised by Prof. Dr. Virginia Vecchioli (Mira, 2017). This research was funded by: National Agency of Scientific Researches and Technologies Promotion Argentina (ANPCyT - FONCyT), initial doctorate scholarship; University of Buenos Aires (UBACyT grants), PhD conclusion; and Erasmus Mundus Action 2 - ARTESS (ARgentina Towards Europe for Socials Sciences) - European Commission, $\mathrm{PhD}$ mobility grant, host university Katholieke Universiteit Leuven (KU Leuven), supervised by Prof. Dr. Stephan Parmentier. This thesis was awarded a Special Mention -Second Prize- in the National Competition of Social Sciences Doctoral Thesis organized by the University of Buenos Aires and EUDEBA (2019).

I would like to acknowledge the blind peer reviewers of this paper for their generosity, help and support for publishing this work. It is with great gratitude that I recognise Prof. Natalia Barbero (University of Buenos Aires) for her valuable time in reading and making comments.

${ }^{3}$ As a convention along this text, words in between inverted commas refer an expression of the agents or natives. They are meant to distinguish the own voice of the legal experts as expressed in the field (in the text, it is mainly a question of allocutions carried out in public events). Words highlighted in italics, on the other hand, indicate the use of analytical categories. This distinction turns out to be central in the perspective of research adopted here and inspired by the ethnographies of the anthropological tradition, which seeks to present the words of the agents and from there to inquire into the sense of their action.

${ }^{4}$ It needs to be highlighted that cause is a polisemic concept, which refers both to a legal proceeding in Court and to a set of interests to be asserted in the public sphere (Gaïti e Israël, 2003). In this paper, the latter understanding is used, in order to refer to a political sense, which is built-up historically and, therefore, needs to be specified (Vecchioli, 2006).
} 
collective action repertoires deployed in pursuit of their goals, which -in the case under study- they synthesized around the idea of "humanizing criminal justice".

With these purposes in mind, this article aims at showing how it is possible to investigate the legal world. Firstly, by explaining the way of an entrée to the field ${ }^{5}$ and the construction of the research field through the participation in the events related to the criminal justice system reform both in the academy and in the public arena. These events constitute spaces for the promotion of alliances and consensus. In other words, the article explains the experience of following the actors in their multiple venues of public action -in the terms of a multilocated ethnography- and of recovering the discourse of the direct protagonists of the criminal justice reform. The methodological research perspective that I applied in my work was guided by the ethnographic premise of recovering the native perspective, a foundation key concerning fieldwork in anthropology.

It is relevant to clarify that the term native is taken from the classic anthropology literature, where it refers to the distinction between the ethnographer and those who belong to the locality that was an object of observation. In this article, the term native is applied to the legal professionals and, more specifically, to the justice "reformers". This distinction among native statements and analytical perspectives is crucial as a heuristic tool, since it allows us to distinguish between the native speeches and their interested point of view and the distant approach from the social sciences. It means that social sciences are supposed not to reproduce these normative points of view but, on the contrary, to understand them sociologically. In this sense -and beyond its truism- much of the challenge of the research was to distinguish the native concepts from the theoretical categories, in order not to silence the natives' voice, on the one hand, and put them in dialogue and, where appropriate, show the tensions among them, on the other.

Secondly, the article presents what is involved in researching one's own culture and the ethnographic journey in the city that is being investigated and, simultaneously, inhabited. Thirdly, the text shows the comprehensive and reflective perspective of the law from the social sciences that explain the reforming cause. Furthermore, the text shows legal activism and cosmologies around this criminal legislative change as central analytical categories to understand the law, as an object of research. In the terms of the actors, it concerns a "struggle" against the remains of the "inquisitive culture" in the country that violates the fundamental rights and guarantees protected by the National Constitution in Argentina.

Lastly, this article presents the main conclusions on how to investigate the legal activism of a group of lawyers who has taken up the cause of human rights in the process of searching for the Republican transformation of criminal justice. The article indeed demonstrates that, in the dispute for the justice reform, these legal experts position themselves as moral entrepreneurs. The "reformers" build-up networks of

\footnotetext{
${ }^{5}$ As a mode of field research entry.
} 
activism beyond Argentina, and dedicate their lives and careers to the cause of law, from an ideology sustained in the democratization of the country and the full enjoyment of human rights.

\section{THE BACKROOM OF RESEARCHING LEGAL ACTIVISM FOR THE REFORM OF the Federal Criminal Procedural Code in Argentina}

My research seeks to understand legal activism to pursue justice reform and the enormous efforts carried out by legal professionals in Argentina, concerning the reform of the Federal Criminal Procedural Code used to try federal crimes. With this purpose, I described the strategies and the resources mobilized by these professionals with the aim of promoting changes in the federal criminal procedural system. Their trajectories, their imaginaries and their worldviews around the law, and the place that experts could occupy in national public life are also analyzed. To this end, from an ethnographic perspective, the participation of legal professionals in the various criminal justice reform projects is understood as an enterprise. The choice of this methodology also requires emphasizing the identification and analysis of the groups involved in these initiatives, the long-term socio-technical disputes around them, and the conditions of possibility of these reforms.

My fieldwork shows the "struggle" between law expert groups to be the legitimate bearers of the flags of the criminal procedural reform, among which are: orality and respect for human rights. In short, it shows a dispute in which the "reformers" seek to establish themselves as representatives of the truth in matters of criminal procedure. This approach makes a turn, showing the adoption of interesting points of view within the activist universe of the lawyers beyond the technical issues of the reform.

\section{II.1. Participation in public events: an entrée to the field}

The starting point of my fieldwork was faced with the central challenge of gaining an entrée to the field -that is, to obtain access- combined with the question of how to do ethnography of elite (Gessaghi, 2012a, 2012b). At the time of the preparation of the fieldwork, it proved extremely complex to be able to define strategies to approach and access to the actors involved in the justice system reform in Argentina, that is to say judges, law professors, parliamentarians, and advocates. This situation originated precisely because of the positions of superiority that these people occupy in society, and even because of the social asymmetry with my own person, when I was doing a field experience to become a researcher. In order to overcome these initial difficulties, various ideas were developed to gain an entrée to the field, from dialogues with some legal experts as key informants, mapping of civil society organizations linked to justice and recognized legal professionals, to attendance at events not so close to the subject in particular but promoted within the legal world.

Finally, the access to the world of the legal reformers was achieved, mainly, throughconstant and long-term participation in events they organized themselves. This 
implies the need of a strong investment in participant observation. In this frame, I found inspiration in Rosana Guber who has raised the productive tension between observation and participation, since "(...) a game is learned by playing a culture one learns by living it. Therefore, participation is the sine qua non of sociocultural knowledge. The tools are the direct experience, the sensory organs and the affectivity that, far from tarnishing, approach the subject matter" (2001:60).

Circulation through the legal world became a research strategy strengthened over time and fruitfully propagated in its scope and achievements. This was possible through the frequent participation in events organized around the reform in a variety of venues, such as universities and civil society organizations, the National Congress and even theatres. The fieldwork terrain itself was affirmed slowly, since it was a deterritorialized terrain, which is equivalent to an area without clear borders or multilocal in Marcus' terminology (1995). The circulation was reminiscent of following the actors (Guber, 1991 and Latour, 2008) in their own labour in different areas, such as the judiciary, parliament, university, media, civil society organizations, professional associations, and law firms.

The referred events mobilized activist resources for reform, where it was possible to find elements of institutional alliances, action plans, inter-personal links, protocols and positions in the legal field. Thus, the circulation and multipositionality of the agents became the founding elements of this ethnography in a double sense. On the one hand, for the understanding of the legal field and, on the other, for the methodological design that consisted in following the actors in the multiplicity of public places where they circulated and acted. The study could not be limited to any of these social venues, but necessarily invited to inquire into bridges, connections, dialogues and inter-linkages between them. Consequently, the communicating vessels -a life sciences concept which I use as a metaphor- between the public world and the private world became visible. They emerged as interpretative keys regarding the composition of the justice reforming elite and of the configuration of their collective actions focused on the exchange of people, resources and expertise. This overview allows us to understand the close connection between legal and political expertise that was noted. For this reason, the research needs to consider what Mark Granovetter called weak ties among the legal experts and its strengh and impact on the criminal justice reform (1978).

The events also functioned as a way of gaining an entrée to the field, generating contacts and building a position as a researcher coming from a universe outside the law in front of the natives. This methodological decision originated as a strategy to overcome the first difficulties in establishing links with legal professionals as important people, with great tasks and multiple occupations, which invites creativity to overcome the challenge (Thomas, 1993). This difficulty was strengthened by the researcher being considered a "lega" (lay person), that means in lawyers jargon a person who does not know about law, in addition of being young and female. These characteristics of the ethnographer translated first into a relationship of the type teacher-student, under which 
I received some master classes, indications for further reading, and even recommendations on research approaches. ${ }^{6}$

As anticipated, in this research the entrée to the field consists in the participation in events of legal experts, that is to say, the frequent attendance to: conferences, congresses, symposia of law, and public audiences at parliament. The diversity of venues of interaction is closely related to the multilocation of these agents and the complexity of the relationships between intimately linked arenas: university, professional associations, non-governmental organizations, law firms, national parliament, and State institutions.

In developing this approach to the events, the research of John Cunha Comerford, who considers them as a type of social encounter representative of the action of the social world, was followed (1999: 48). From this conception, the events constitute spaces of socialization that allow to identify individual, public and private institutional agents; and to know their discourses, positions and trajectories. At the same time, the events allow to appreciate aspects of negotiations, agreements or disagreements and possible alliances among them in pursuit of their common objective synthesized in achieving the reform.

In these social events different features, beyond the content of the speeches on the bill, become visible: styles (Bourdieu, 1996 and Cuhna Comerford, 1999), hierarchies, liturgical conditions (Bourdieu, 1996), spatial provisions, languages and networks of experts at both the national and international levels. These features are known as ritual events (Vecchioli, 2014: 71). It is also valuable in sociological terms that activities in the form of events presuppose for their realization: objectives, protocols -order and duration of procedures- programming, coordination, discussions, conclusions, papers, and participants (Cunha Comerford, 1999: 48).

Following this strategy, it was possible to approach the legal field and its agents. Over the time, the possibility of accessing to the reform experts in situ was expanded, and it has been possible to interview them. It is worth highlighting how my presence as a researcher contributed -in some cases- to generate among the natives a tacit assumption of my closeness or connection to the group. This facilitated the articulation of exchanges that, for example, allowed me to organize personal interviews with the main protagonists. At the same time, these events were not only a space of observation but also a tactic generated by legal experts in pursuit of the reform promotion and its values in relation to justice. It means that these collective actions or events allow the "reformers" to present their ideas, to show their alliances and to spread their reform message to the audience. For this reason, the events also constituted the raw material for the resource mobilization of the reform protagonists, and the collective actions that they undertook in order to "struggle" for their cause.

\footnotetext{
${ }^{6}$ A similar experience in the fieldwork was reported by María José Sarrabayouse Oliveira (2009), as well as the complexity of making this relationship in the sense of etnographer-informant.
} 


\section{II.2. Native etnographer: The journey to the social world of lawyers}

Another question that arises regarding the entrée to the field is a tension in doing ethnography in one's own culture while, at the same time, being alien to the legal world. My interest was thus set at discovering how to achieve proximity to that world of relationships without having any personal relationships or professional ties -at least at that time- with the legal world. I carried out many attempts, several of which were frustrating for a long time. During this period, I did not succed in completing my role as a researcher within a framework of both remoteness and closeness.

The feeling of disorientation was a constituent part of the initial moment regarding my research. In that way, unknowingly, the initiatory journey of my ethnography had begun without even having moved away from the city where I lived. I arrived in a strange world and thus the anthropological experience amalgamated, in terms of native anthropologist (Guber, 2001: 38). The words of Roberto Da Matta resonate when he recounts the shamanic experience in a journey that "does not leave the place". The "shamanic journeys are vertical journeys (inwards or upwards) rather than horizontal as happens with the classic journey of the Homeric heroes", because "somehow they set out to reach the bottom of the well of their own culture" (1974: 175). It is from this understanding that the opportunity of an inner journey opens for the researcher himself.

All these elements show that eventhough it is not a trip to distant lands, like those undertaken by classical anthropologists, my fielwork required a journey to a world that was symbolically as exotic as it was close in terms of territory: the social world of lawyers committed to criminal justice reforms (Sabarrayrouse Oliveira, 2009). This trip emulated, in part, the classic anthropological journey both by the method and by the analytical tools that proved useful when assessing the material gathered in the field. The categories and concepts belonging to classical anthropology to address "distant" or "exotic" societies were productively recovered to study lawyers nowadays: kinship, lineage, tradition, authority, alliances, ritual, gift and prestige, among others. All of them emphasize the social relations between the various members of the legal field. This is relevant as the culture "is the whole of those relations", which presents at the same time "an intellectual, symbolic dimension, and a concrete, historical and sociological dimension through which its implementation is developed" (Augé, 2006: $31)$.

The shaping of an anthropological experience conducting research and writing demands simultaneously "being outside and inside, being distant and participating" (Augé, 2006: 58). The challenge of "the anthropological perspective involves both a transformation of the exotic into the familiar, and of the familiar into the exotic", synthesizes María José Sarrabayrouse Oliveira from her experience as a researcher about the recent history of justice in Argentina (2009: 67). "The problem is, then, to divest oneself as a member of a class and of a specific social group in order to be able as an ethnologist- to render strange or defamiliarise some familiar social rule", points 
out clearly Roberto Da Matta; because there lies the possibility to "discover (...) the exotic in what is petrified within us by reification and by the mechanisms of legitimization" (1974: 267). With these premises as a lighthouse, my ethnographic fieldwork was construed by successive approximations.

\section{PRODUCING A COMPREHENSIVE PERSPECTIVE CONCERNING LAW FROM THE SOCIAL SCIENCES: NATIVE CATEGORIES AND THEORETICAL CONCEPTS}

To produce a comprehensive perspective concerning law from the social sciences, as encouraged by Virginia Vecchioli, requires the effort of a distant reflection: "the way in which those interested reflect on these topics and affirm the value of that basic principle of the social sciences that points out the need to transcend the explanations grounded on the will of the agents themselves" (2011: 5). As previously mentioned, my research focuses on the point of view of legal professionals and their accounts of their commitment to the cause of the justice reform related to the human rights and democracy defense. These stories were taken as a source to be subjected to criticism, and in the approach I was especially careful to avoid the enchantment or seduction that usually generates this type of native rhetoric (Augé, 2006 and Vecchioli, 2006).

In this search for understanding, various analytical categories were used as tools to reflect on the construction of criminal justice reform as an object belonging to the sociology of law: cause and cosmology. These categories of analysis mainly address the social and cultural production of law. In order to put in context such an approach to the object of study, each of these categories, which facilitated the research are presented below.

\section{III.1. Cause-based "partisanism" (militancia) and legal activism}

In the research, the legal professionals working to promote the cause of the Federal Criminal Procedural Code reform were considered from a multidimensional perspective because these professionals mobilized a series of activist resources to criticize the current legislation and promote a new legal text by proposing new draft codes. Resources include, for example, the use of public arena, the belonging to institutions and associations, the prestige, the public speaking, all of which constitute social and symbolic capital (Bourdieu, 1996). In this frame, it is really significant that the group of legal professionals involved in this cause called themselves "reform partisans" (or militantes in Spanish).

This case demonstrates the complexity of studying elites from the social sciences perspectives, as it places us up against the challenge of researching agents in venues of power that are not circumscribed to the parliament, the justice system, or executive branch. On the contrary, the "reformers" occupy multilocated positions both in the State and in civil society. They are advisers to parliamentarians, lawyers who exercise the profession privately, university professors, members of the judiciary, and/or members of civil society organizations or associative institutions of legal professionals. 
The mobilization of legal professionals makes it possible that the justice reform becomes the solution to the social problems which they describe. Examples, that the "reformers" themselves make public, include a number of great court cases for corruption stopped due to the existing statute of limitations. According to the "reformers", this type of cases shows the lack of efficiency of the Federal Criminal Procedural Code. Thus, these cases give rise to the moral competence of the legal reforming discourse (Siméant, 2002). In terms of the law, as a language and means of action, it is the legal expert intervention that transforms the reform of federal criminal procedure into a response to impunity and thus seeks to install both a public and collective cause. The legal field operates as a principle of reality construction, Pierre Bourdieu (1986) emphasizes, once the ordinary situations are redefined according to its legal definition. To sum up, this research, by focusing on this professional group, seeks to present the force of law (Bourdieu, 1986) invested in shaping this cause, which strives to install federal criminal procedural reform as something essential for society as a whole.

\section{III.2. Reform flags as cosmologies of social order}

The notion of cosmology is revealing of the positions of legal experts on the cause of criminal justice reform. Mary Douglas (1966, 1986 and 1988) argues that cosmologies, as ideal representations of the social order, are tools that agents use to discern, analyse and value reality. Douglas believes that cosmologies are exposed in classifications, theodicies, analogies, arguments and conventions. The use of cosmologies as a resource becomes especially necessary when anomalies occur, that is, at times when agents identify disorder confronted with what they consider the natural order.

This research made it possible to identify at least three key cosmological arguments that intensely cut across the discourse of the "reformers". These arguments are constitutive of their critique of the "inquisitive system" and the engine for their proposal of "accusatory system". These cosmologies are a) "the humanization of criminal justice"; b) "the prosecution of the great crime"; and c) the strengthening of human rights and democratization. These representations and narratives contribute to shape the moral force in the struggle of the "reformers" against the "inquisitive system". It is worthy to say that the "reformers" consider that this form of criminal prosecution crystallises in the file record, as an artifact, which expresses its inefficiency in prosecuting crimes linked to power, and results in undermining persons when they face a criminal conflict under the judiciary system and before the courts.

The ethnographic disposition to follow the actors facilitated a glimpse of the trajectories and the participation in events of legal professionals, where both their expert work and their feature as moral entrepreneurs stand out. Experts become activists because they turn their work for reform into a real cause for which they fight and "militate". This legal activism drives a dual movement, as it simultaneously builds their identities and shapes their professional and activist careers. The nature of the work of 
the "reformers" leads to the verification of a hybridization between their expert and activist knowledge in the struggle for another criminal procedural system (Siméant, 2002). The "reformers" equate this legal transformation with a process aimed at "the fight against the mafias", the conquest of "citizen participation" and the "democratization of justice". One final remark, these expressions emanating from cosmologies make it possible to recover the transcendence of the cultural dimension for (re)thinking the law and its reforms.

\section{CONCLUSIONS: THE RESEARCH INTO THE LEGAL WORLD AS A JOURNEY}

Showing the backroom of this research allows us to make various contributions. First, it shows that ethnographic work requires being adapted to the characteristics of groups and the legal world, as well as to the dynamics of the field. This adaptation needs, as it has been shown, a great investment of time and creativity to overcome the difficulties inherent in gaining access into this particular field and to high-profile personalities. The strategy of being there facilitates the perception of events as an opportunity to get in contact, both with the actors and with the public debates. However, this path requires errors, failed searches and new beginnings that are all necessary to configure an entrée to the field and its agents.

The second contribution of showing the making of the research lies in the fundamental richness of being willing to start an ethnographic journey within the same culture -the "vertical journey" suggested by Da Matta. This implies the willingness to learn the language of the natives, which might seem the same language but becomes distinct by using technical vocabulary that separates the native users from the rest of the population, where the researcher is included. This is another key to conducting ethnographies in one's own culture, where distance is built and reissued in specific forms, without journeys to distant and exotic places. Hence, the voice and words of the protagonists have a great value in themselves. For this reason, it is necessary to differentiate them from the analyses that we as social scientists carry out, securing that neither the voice of the natives nor the reflection of the researcher are made invisible or merge in each other.

From this approach, we are invited to recover the potential of the comprehensive perspective that can be materialized from the social sciences to address the social construction of law. This strategy is needed to be applied both at the time of analysis of data, and later when writing the results. This exercise offers the opportunity to generate new social knowledge about the legal world, which does not reproduce the discourse of the agents, enchanted views, or interpretations that overshadow the social production of law.

Finally, my research shows the need to keep this debate open in the social sciences, in order to recover the legal field as a venue of social inquiry. From this perspective, it is possible to research renewed questions and to find renewed answers around justice, human rights and legal power considering their extraordinary weight in 
today's society worldwide. To put it simple, for understanding the law we need to research beyond the law.

\section{REFERENCES}

Augé, Marc (2007) [2006]. El oficio de antropólogo. Sentido y libertad. Gedisa: Barcelona.

Bourdieu, Pierre (2001) [1982]. ¿Qué significa hablar? Economía de los intercambios lingüísticos. Ed. Akal: España. https://doi.org/10.17227/01203916.5476

Bourdieu, Pierre (1986). "La force du droit. Éléments pour une sociologie du champ juridique", Actes de la Recherche en Sciences Sociales, 64, sept. 1986. [Traducción al español: "La fuerza del derecho: elementos para una sociología del campo jurídico" (2000), en Poder, derecho y clases sociales. Desclée de Brouwer: Bilbao, pp. 165-223]. https://doi.org/10.3406/arss.1986.2332

Bourdieu, Pierre (1996). A economia das trocas lingüísticas. O que falar quer dizer. EDUSP: San Pablo.

Cunha Comerford, John (1999). Fazendo a Luta. Sociabilidades, Fales e Rituais na Construção de Organizações Camponesas. Relume Dumará: Rio de Janeiro.

Da Matta, Roberto (1998) [1974]. "El oficio del etnólogo o cómo tener 'Anthropological Blues'", Boivin, F., Rosato, A.; Arribas, V. (eds.). Constructores de otredad. EUDEBA: Buenos Aires, pp. 263-272.

Douglas, Mary (2007) [1966]. Pureza y peligro. Un análisis de los conceptos de contaminación y tabú. Buenos Aires: Nueva Visión.

------ (1986). How Institutions Think. Nueva York: University of Syracuse Press.

-----. (1988). Símbolos naturales. Exploraciones en cosmología. Madrid: Alianza Editorial.

Gaït, Brigitte e Israël, Liora (2003). "Sur 1'engagement du droit dans la construction des causes", Revista Politix. Paris. Vol. 16, Nro. 62, pp. 17-30. https://doi.org/10.3406/polix.2003.1274

Gessaghi, Victoria (2012a). "Elites, construcciones históricas y recomposiciones contemporáneas", Gessaghi, Victoria y Ziegler, Sandra (comp.). Formación de las elites. Investigaciones y debates en Argentina, Brasil y Francia. Editorial Manantial-FLACSO: Buenos Aires.

Gessaghi, Victoria (2012b). "La clase anta en la encrucijada: 'Heredar la valija de San Martín o hacerse profesionales'”, Ziegler, Sandra y Gessaghi, Victoria (comps.). La formación de las elites en la Argentina. Nuevas investigaciones y desafios contemporáneos. Manantial-FLACSO: Buenos Aires.

Guber, Rosana (1991). El salvaje metropolitano. A la vuelta de la antropología postmoderna. Reconstrucción del conocimiento social en el trabajo de campo. Legasa: Buenos Aires. 
-----. (2001). La etnografía. Método, campo y reflexividad. Norma: Buenos Aires.

Granovetter, Mark (1978). "The strength of weak ties", American Journal of Sociology, vol. 78, n 6, pp. 1360-1380 [Edición en español: "La fuerza de los vínculos débiles" en Política y sociedad, vol. 33, 2000, Universidad Complutense de Madrid, pp. 41-56].

Latour, Bruno (2008) [2007]. Reensamblar lo social: una introducción a la teoría del actor-red. Manantial: Buenos Aires.

Marcus, George (1995). "Etnography in/of the World System. The emergence of multisited ethnography", Annual Review of Anthropology, $\mathrm{N}^{\circ}$ 24, pp. 95-117 [Traducción al español: Marcus, George (2001). "Etnografía en/del sistema mundo. El surgimiento de la etnografía multilocal", en Alteridades, 11 (22), pp. 111-127]. https://doi.org/10.1146/annurev.anthro.24.1.95

Mira, Julieta (2017). "Una promesa de democratización. Activismo, política y expertise jurídica en el proceso de reforma de la justicia penal en la Argentina”, Doctoral Thesis, Doctoral Programme, Faculty of Social Sciences, Universtiy of Buenos Aires.

Sarrabayrouse Oliveira, María José (2009). "Reflexiones metodológicas en torno al trabajo de campo antropológico en el terreno de la historia reciente". Cuadernos de Antropología Social, № 29, Facultad de Filosofía y Letras - Universidad de Buenos Aires, pp. 61-83.

Siméant, Johanna (2002). "Friches, hybrides et contrebandes: sur la circulation et a puissance militantes des discours savants", Hamman, Philippe; Méon, JeanMatthieu y Verrier, Benoit (directores). Discours savants, discours militants: Mélange des genres. L’Harmattan: Paris, pp. 17-53.

Thomas, Robert (1993). "Interviewing Important People in Big Companies", Journal of Contemporary Ethnography, vol. 22, N${ }^{\circ}$, abril 1993, pp. 80-96. https://doi.org/10.1177/089124193022001006

Vecchioli, Virginia (2006). A luta pelo direito. Engajamento militante $e$ profissionalização dos advogados na causa pelos direitos humanos na Argentina. Tesis doctoral, Programa de post-graduación en Antropología Social, Universidad Federal de Río de Janeiro, Museo Nacional: Río de Janeiro.

------. (2011). "Presentación: Profesionales del derecho, activismo jurídico y creación de nuevos derechos. Hacia una mirada comprensiva del derecho desde las ciencias sociales", Revista Política, Universidad de Chile, Vol. 49, No 1, pp. 5-18. https://doi.org/10.5354/0716-1077.2011.16268

-----. (2014). "La recreación de una comunidad moral y la institución de un relato legítimo sobre los derechos humanos en la Argentina", Publicar, Año VXII, N ${ }^{\circ}$ XVII - Diciembre 2014, pp. 1-27. 